\title{
Alkylation of in situ generated fluorinated alkoxides: novel synthesis of partially fluorinated ethers
}

\author{
G. K. Surya Prakash*, Jinbo Hu and George A. Olah \\ Loker Hydrocarbon Research Institute and Department of Chemistry, University of Southern \\ California, University Park, Los Angeles, CA 90089-1661 \\ E-mail:gprakash@usc.edu
}

Dedicated to Professor Sukh Dev on the occasion of his $80^{\text {th }}$ birthday

(received 07 Jan 03; accepted 24 Feb 03; published on the web 27 Feb 03)

\begin{abstract}
Fluorinated ethers $\mathrm{R}_{\mathrm{f}} \mathrm{CF}_{2} \mathrm{OR}$ were prepared from acyl chlorides $\mathrm{R}_{\mathrm{f}} \mathrm{COCl}$, alkylating agents (such as dimethyl sulfate, alkyl triflates, alkyl mesylates and tosylates, etc.) and potassium fluoride in diglyme at $80 \sim 100{ }^{\circ} \mathrm{C}$. The success and the efficiency of the reaction are affected by two factors: the stability and nucleophilicity of the fluorinated alkoxide generated in situ; and the other is the electrophilicity of the alkylating agents used.
\end{abstract}

Keywords: Fluoroethers, fluoroacyl halides, fluoride ion, alkylation

\section{Introduction}

In general, carbon-fluorine bonds (C-F, $\sim 116 \mathrm{kcal} / \mathrm{mol})$ are stronger than carbon-hydrogen bonds (C-H, $99 \mathrm{kcal} / \mathrm{mol}) .{ }^{1}$ However, not all organofluorine compounds are more stable than their non-fluorinated analogs, and sometimes they are even less stable. For instance, if a partially or fully fluorinated organic compounds contains an acidic hydrogen at the $\beta$ position, HF elimination is observed. This is the main reason that $\alpha$-fluoro alcohols are thermally unstable and difficult to be synthesized or isolated. ${ }^{2}$ Formation of fluoromethanol $\left(\mathrm{FCH}_{2} \mathrm{OH}\right)$ from ethyl fluoroformate and from formyl fluoride was first reported by Olah and Pavlath ${ }^{3}$ in 1953, and Weinmayer ${ }^{4}$ in 1963 claimed the formation of fluoromethanol (25-30\% in equilibrium) from a solution of paraformaldehyde in excess hydrogen fluoride. But both research groups were unable to isolate and characterize the pure compound. Trifluoromethanol $\left(\mathrm{CF}_{3} \mathrm{OH}\right)$ has been prepared, purified and characterized from trifluoromethyl hypochlorite and hydrogen chloride by Kloter and Seppelt ${ }^{5}$ in 1979 , but it decomposes readily above $-20{ }^{\circ} \mathrm{C}$. Stable protonated $\alpha$-fluoro alcohols in condensed state or in crystalline state have been known, such as protonated fluoromethanol $\left(\mathrm{FCH}_{2} \mathrm{OH}_{2}{ }^{+}\right)$by Olah and Mateescu, ${ }^{6}$ protonated heptafluoroisopropanol 
$\left\{\left(\mathrm{CF}_{3}\right)_{2} \mathrm{C}(\mathrm{F}) \mathrm{OH}_{2}{ }^{+}\right\}$by Minkwitz and Reinemann, ${ }^{7}$ and protonated trifluoromethanol $\left(\mathrm{CF}_{3} \mathrm{OH}_{2}{ }^{+}\right)$ by Christe and co-workers. ${ }^{8}$ However, to our knowledge, the only reported $\alpha$-fluoro alcohol stable in the pure state at ambient temperature is heptafluorocyclobutanol $\left(\mathrm{C}_{4} \mathrm{~F}_{7} \mathrm{OH}\right)$, which was prepared from hexafluorocyclobutanone and hydrogen fluoride by Andreades and England ${ }^{9}$ in 1961. All these difficulties in the preparation and isolation of $\alpha$-fluoro alcohols make them not practical as reagents for organic synthesis, especially for the generation of $\alpha$-fluoro alkoxide $\left(\mathrm{R}_{\mathrm{f}} \mathrm{O}^{-}\right)$synthon.

$\alpha$-Fluoroalkoxides, particularly perfluoroalkoxides, have been reported for more than thirty years. The first preparations of reasonably stable, crystalline perfluoroalkoxides of alkali metals, i.e. $\mathrm{R}_{\mathrm{f}} \mathrm{OM}\left(\mathrm{R}_{\mathrm{f}}=\mathrm{CF}_{3}, \mathrm{M}=\mathrm{K}, \mathrm{Rb}\right.$ or $\mathrm{Cs} ; \mathrm{R}_{\mathrm{f}}=\mathrm{CF}_{3}, \mathrm{C}_{2} \mathrm{~F}_{5}, \mathrm{C}_{3} \mathrm{~F}_{7}$ or perfluoroisopropyl group, $\mathrm{M}=\mathrm{Cs}$ or Rb), were reported by Redwood and Willis ${ }^{10}$ in 1965 and 1966. Pittman, ${ }^{11}$ Evans ${ }^{12}$ and their coworkers also reported the formation of adducts between fluorinated ketones and metal fluorides in 1965 and 1968, respectively. Above room temperature $\left(20^{\circ} \mathrm{C}\right)$, these metal perfluoroalkoxides decompose into metal fluorides and acyl fluorides or ketones, ${ }^{10}$ which indicates their relatively lower nucleophilicity compared with their non-fluorinated alkoxide analogs. And in the following twenty years, only few synthetic applications of these perfluoroalkoxides have been explored, such as reactions with unsaturated acyl chloride, ${ }^{13}$ with allyl bromide, ${ }^{10 \mathrm{~b}}$ with olefin in the presence of a halogen, ${ }^{14}$ with epibromohydrin ${ }^{11}$ and fluoroolefin epoxides. ${ }^{15}$ Tris(dimethylamino)sulfonium trifluoromethoxide $\left(\mathrm{TAS}^{+} \mathrm{CF}_{3} \mathrm{O}^{-}\right)$was also reported as a stable crystalline compound by Farnham and co-workers in $1985,{ }^{16}$ but its synthetic application has not been well investigated.

In the last decade, partially fluorinated ethers, or so-called "hydrofluoroethers (HFE)", have attracted increasing attention as refrigerants especially in industry as promising substitutes for the ozone-depleting chlorofluorocarbons (CFCs). According to Montreal Protocol and its appended amendments, the production and use of CFCs must be discontinued. ${ }^{17}$ Partially fluorinated ethers $\left(\mathrm{R}_{\mathrm{f}} \mathrm{OR}\right)$, as a class of compounds, are particularly spotlighted as promising replacements for CFCs, not only because of their zero ozone depleting potential and low toxicity, but also they exhibit excellent solvent properties - they dissolve both hydrocarbon based and fluorocarbon based materials. ${ }^{18}$ These partially fluorinated ethers can be extensively used as detergents, solvents, lubricants, heat-transfer media, and so on. ${ }^{19,20}$ These fluoroethers can be synthesized by two categories of methods: direct fluorination (with elemental fluorine) of the hydrocarbon ether compound, and methods wherein the ether linkage is formed during the reaction with a fluorinated precursor. ${ }^{18,21}$ The latter methods are more popular, such as acid catalyzed alkylation of perfluoroacyl fluoride with alkyl fluoride, ${ }^{18}$ and alkylation of perfluorinated alkoxides prepared by the reaction of the corresponding perfluorinated acyl halide or perfluorinated ketone with an anhydrous metal fluoride in anhydrous polar, aprotic solvent. ${ }^{19,22-24}$ Since the acid catalyzed alkylation of perfluoroacyl fluorides normally gives low yields and complex isomerization products, ${ }^{18}$ non-catalytic alkylation of perfluoroalkoxides shows the more attractive practical features for industrial applications. Although in the recent years there have been several disclosures on this methodology using different alkylating agents 
(such as alkyl fluorovinylalkyl ether, ${ }^{25}$ dimethyl sulfate ${ }^{19}$ and alkyl triflate ${ }^{26}$ ); gaseous shortchain perfluoroacyl halides are often used, and the results are only recorded in industrial patents without full characterization or experimental details.

Recently, we were interested in developing new types of fluorinated compounds as low temperature lithium battery electrolyte co-solvents. Partially fluorinated ethers were some of our prime candidates, since these compounds can increase the battery's discharge capacity during charge/discharge cycle, by forming a stable coating on the surface of the negative electrode and suppressing the degradation of the non-aqueous electrolyte. ${ }^{27,28}$ Herein, we wish to report the synthesis of these partially fluorinated ethers by alkylating fluorinated alkoxides generated in situ by treating short or long chain fluorinated acyl chlorides with potassium fluoride.

\section{Results and Discussion}

\section{Dimethyl sulfate as the alkylating agent}

Dimethyl sulfate is a powerful alkylating agent and has been used for the methylation of almost every imaginable nucleophile. ${ }^{29}$ Using dimethyl sulfate as the methylating agent, we successfully synthesized fluoroalkyl methyl ethers 2 (see Scheme 1).

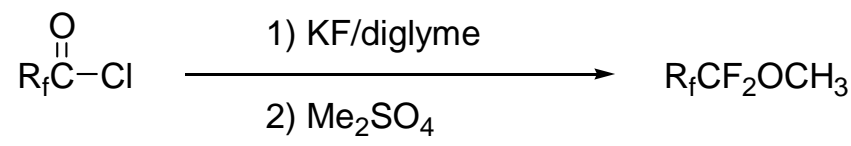

1

2

\section{Scheme 1}

Fluorinated acyl chlorides $\mathbf{1}$ are the preferred precursors for the generation of 1,1difluoroalkoxides, since fluoroacyl chlorides have higher boiling points than the corresponding fluoroacyl fluorides.

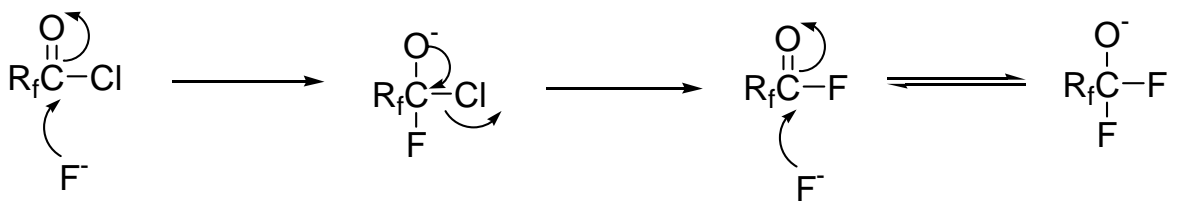

\section{Scheme 2}


During the reaction, fluoroacyl chloride can be fluorinated by KF to fluoroacyl fluoride $\mathbf{4}$ in situ, ${ }^{19}$ and the latter is easily transformed into fluoroalkoxide 5 (see scheme 2). Diglyme is the solvent of choice due to it's high polarity and excellent solvation of the in situ generated fluorinated alkoxides $\mathbf{5} .^{19,25}$

Typical reaction condition is as follows: perfluorooctanoyl chloride $1 \mathrm{a}(30 \mathrm{mmol})$ is reacted with anhydrous KF $(90 \mathrm{mmol})$ in dry diglyme at $50{ }^{\circ} \mathrm{C}$ for 30 minutes, followed by a slow dropwise addition of dimethyl sulfate $(60 \mathrm{mmol})$ at $70{ }^{\circ} \mathrm{C}$. The reaction mixture was kept at 70 $\sim 100{ }^{\circ} \mathrm{C}$ for another 1 hour, cooled to room temperature and stirred overnight. The ester byproduct $\left(\mathrm{R}_{\mathrm{f}} \mathrm{COOMe}\right)$ can be removed from the ether product 2 simply by stirring the reaction mixture with $\mathrm{NaOH}$ aqueous solution. After workup, perfluorooctyl methyl ether 2a can be isolated in $80 \%$ yield.

As shown in table 1, both short chain perfluoroacyl $\left(\mathrm{C}_{1} \sim \mathrm{C}_{4}\right)^{19}$ and long chain perfluoroacyl chlorides $\left(\mathrm{C}_{7} \sim \mathrm{C}_{9}\right)$ gave good yields of methylated products 2a 2c. For the other nonperfluorinated substrates 1d and 1e, the reactions gave lower yields. For the substrates without fluorine atoms at the $\alpha$-carbon to the carbonyl group (see $\mathbf{1 g}$ and $\mathbf{1 h}$ ), the reaction did not take place. Varying yields of fluoroethers can be roughly explained by the stability and the nucleophilicity of each fluoroalkoxide $5\left(\mathrm{R}_{\mathrm{f}} \mathrm{CF}_{2} \mathrm{O}^{-}\right)$generated in situ in the reaction. Since these fluoroalkoxides exist in equilibrium with metal fluoride and fluoroacyl fluorides under the reaction conditions, as shown in scheme 2, the weaker fluoroalkoxide would have a higher tendancy to decompose into the metal fluoride and acyl fluoride. Among these fluoroalkoxides $\mathbf{5}$, the trifluoromethoxide ion (i.e. $\mathrm{R}_{\mathrm{f}}=\mathrm{F}$ ) is the most stable one, because the negative charge on the trifluoromethoxide ion rests formally on the oxygen atom, with the negative charge being shared to some extent by the three fluorine atoms because of their greater electronegativity. ${ }^{10}$ When the $\mathrm{R}_{\mathrm{f}}$ is changed to a perfluoroalkyl group, such as in $\mathbf{1 a}, \mathbf{1 b}$ and $\mathbf{1 c}$, the longer the perfluoroalkane chain makes the carbon atom connecting to $\mathrm{CF}_{2} \mathrm{O}^{-}$less electronegative, resulting in the lower stability of the resulting alkoxide and then somewhat lower yields of the ethers. When $\mathrm{R}_{\mathrm{f}}=\mathrm{Cl}$ (1d), the ether yield is moderate; and when $R_{\mathrm{f}}=$ phenyl group (1e), the yield of ether is much lower because the phenyl group has even weaker electron-withdrawing ability than the chlorine

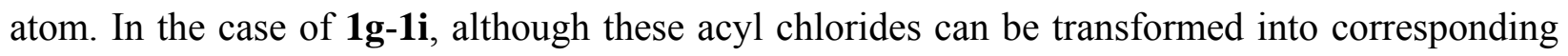
acyl fluorides $\mathbf{4 g}-\mathbf{4 i}$ (characterized by NMR), they failed to produce the ether product $\mathbf{2 g}, \mathbf{2} \mathbf{h}$ or $2 \mathbf{i}$ indicating that these acyl fluorides $4 \mathbf{g}-4 \mathbf{i}$ are not further fluorinated into alkoxides $\mathbf{5 g}-\mathbf{5 i}$, probably due to their instability. Finally, it is also remarkable that the diacyl chloride $1 \mathrm{f}$ can be transformed into the diether $\mathbf{2} \mathbf{f}$ in good yield.

Table 1. Preparation of fluoroethers 2 from fluorinated acyl chlorides $\mathbf{1}, \mathrm{KF}$ and dimethyl sulfate in diglyme 


\begin{tabular}{|c|c|c|c|}
\hline & $\begin{array}{c}\text { Reactants } \\
\mathbf{1}\end{array}$ & $\begin{array}{c}\text { Products } \\
\mathbf{2}\end{array}$ & Yields (\%) ${ }^{\mathrm{a}}$ \\
\hline a & $n-\mathrm{C}_{7} \mathrm{~F}_{15} \mathrm{COCl}$ & $n-\mathrm{C}_{8} \mathrm{~F}_{17} \mathrm{OCH}_{3}$ & 80 \\
\hline b & $n-\mathrm{C}_{8} \mathrm{~F}_{17} \mathrm{COCl}$ & $n-\mathrm{C}_{9} \mathrm{~F}_{19} \mathrm{OCH}_{3}$ & 71 \\
\hline c & $n-\mathrm{C}_{9} \mathrm{~F}_{19} \mathrm{COCl}$ & $n-\mathrm{C}_{10} \mathrm{~F}_{21} \mathrm{OCH}_{3}$ & 62 \\
\hline d & $\mathrm{CClF}_{2} \mathrm{COCl}$ & $\mathrm{CClF}_{2} \mathrm{CF}_{2} \mathrm{OCH}_{3}$ & 48 \\
\hline e & & $\mathrm{CF}_{2} \mathrm{OCH}_{3}$ & 23 \\
\hline$f$ & $\mathrm{ClOC}^{-}$ & $\mathrm{CH}_{3} \mathrm{OCF}_{2} \mathrm{CF}_{2} \mathrm{CF}_{2} \mathrm{CF}_{2} \mathrm{CF}_{2} \mathrm{OCH}_{3}$ & 50 \\
\hline g & $-\mathrm{CC}$ & $-\mathrm{CF}_{2} \mathrm{OCH}_{3}$ & $0^{b}$ \\
\hline h & 1) $\mathrm{CC}$ & $-\mathrm{CF}_{2} \mathrm{OCH}_{3}$ & 0 \\
\hline $\mathbf{i}$ & $\mathrm{Cl}-\stackrel{\mathrm{I}}{\mathrm{C}}-\stackrel{\mathrm{II}}{\mathrm{C}}-\mathrm{Cl}$ & $\mathrm{CH}_{3} \mathrm{OCF}_{2} \mathrm{CF}_{2} \mathrm{OCH}_{3}$ & 0 \\
\hline
\end{tabular}

${ }^{a}$ All are isolated yields; ${ }^{b}$ methyl triflate was also tried as methylating reagent, but the reaction was not successful.

The relative stability and nucleophilicity of fluoroalkoxide 5 can also be explained by the negative hyperconjugation $(\mathrm{HCJ})^{30}$ as shown in Scheme 3. Farnham and coworkers have explained the structural parameters of $\left(\mathrm{Me}_{2} \mathrm{~N}\right)_{3} \mathrm{~S}^{+} \mathrm{CF}_{3} \mathrm{O}^{-}$by HCJ. Their evidence for $\mathrm{HCJ}$ is that the X-ray structure shows the $\mathrm{C}-\mathrm{O}$ bond to be unusually short $(1.227 \AA)$ and the $\mathrm{C}$-F bond is extraordinarily long (1.390-1.397 $\AA) .{ }^{16 a}$ Thus we can derive that for the other fluorinated alkoxides $\left(R_{f} \neq F\right)$, strong electron-withdrawing property of $R_{f}$ group may facilitate the HCJ between $\mathbf{5 a}, \mathbf{5 b}$ and $\mathbf{5 c}$, which stabilizes the corresponding alkoxides and increases their propensity to react with alkylating agents such as dimethyl sulfate. 
(a)

$$
\begin{aligned}
\left(\mathrm{Me}_{2} \mathrm{~N}\right)_{3} \mathrm{~S}^{+} & \mathrm{C}_{\mathrm{F}}^{-\mathrm{O}} \\
\mathrm{C}-\mathrm{F}: 1.227 \AA & 1.390-1.397 \AA
\end{aligned}
$$

(b)

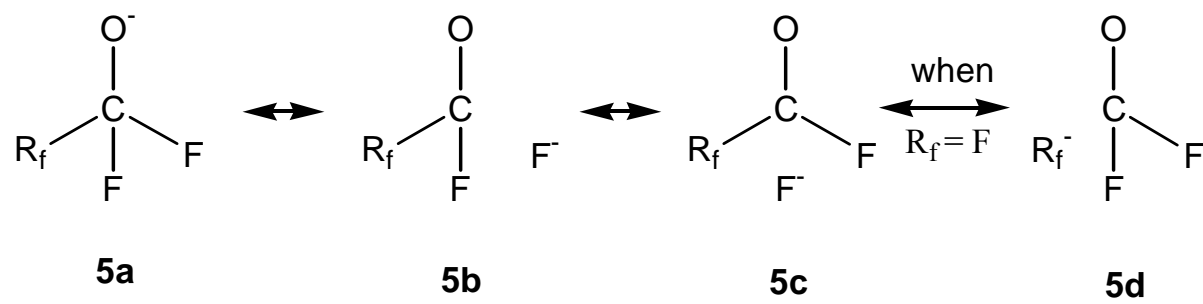

Scheme 3. (a) C-O and C-F Bond lengths from $\left(\mathrm{Me}_{2} \mathrm{~N}\right)_{3} \mathrm{~S}^{+} \mathrm{CF}_{3} \mathrm{O}^{-}$X-ray crystal structure; ${ }^{16 a}$ (b) Negative hyperconjugation in fluorinated alkoxide (5).

\section{Alkyl sulfonates as alkylating agents}

Besides dimethyl sulfate, we also attempted to use other strong alkylating agents to prepare partially fluorinated ethers, such as methyl trifluoromethanesulfonate (methyl triflate), ethyl triflate, hexyl triflate, methyl methanesulfonate (methyl mesylate) and methyl $p$-toluenesulfonate (methyl tosylate). The reaction conditions were similar to previously studied reactions with dimethyl sulfate (Scheme 4).

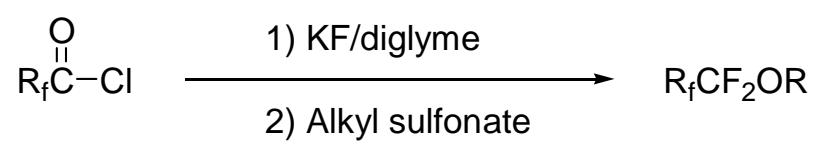

1

6

\section{Scheme 4}

The results are summarized in Table 2.

Table 2. Preparation of fluoroethers 6 from $n$-perfluorooctanoyl chloride, 1, KF and alkyl sulfonates in diglyme 


$\left.\begin{array}{lll}\begin{array}{l}\text { Alkyl } \\ \text { sulfonate }\end{array} & \begin{array}{c}\text { Products } \\ \mathbf{6}\end{array} & \text { Yields (\%) } \\ \hline \mathrm{CF}_{3} \mathrm{SO}_{3} \mathrm{CH}_{3} & n-\mathrm{C}_{8} \mathrm{~F}_{17} \mathrm{OCH}_{3} & 82 \\ \text { Methyl mesylate } & n-\mathrm{C}_{8} \mathrm{~F}_{17} \mathrm{OCH}_{3} & 29 \\ \text { Methyl tosylate } & n-\mathrm{C}_{8} \mathrm{~F}_{17} \mathrm{OCH}_{3} & 17 \\ \mathrm{CF}_{3} \mathrm{SO}_{3} \mathrm{Et} & n-\mathrm{C}_{8} \mathrm{~F}_{17} \mathrm{OCH}_{2} \mathrm{CH}_{3} & 34 \\ & n-\mathrm{C}_{8} \mathrm{~F}_{17} \mathrm{OCH}_{3} & 51\end{array}\right\} 85$

${ }^{\text {a }}$ All are isolated yields.

The effect of different alkylating agents on the yields of ether product $\mathbf{6}$ can be clearly seen from Table 2 (entries a-c). Since the order of methylating ability is methyl triflate $>$ methyl mesylate $>$ methyl tosylate, the yields of methyl perfluorooctyl ether are in the same order. It is interesting note that in the case of ethylation and hexylation reactions using ethyl triflate and hexyl triflate, respectively (entries $\mathbf{d}$ and $\mathbf{e}$ ), each reaction gives the methyl ether $\left(n-\mathrm{C}_{8} \mathrm{~F}_{17} \mathrm{OCH}_{3}\right)$ besides expected product ( $\mathbf{6 d}$ or $\mathbf{6 e}$ ). The mechanism of formation of methyl ether is proposed as shown in Scheme 5 involving disproportionation reactions.

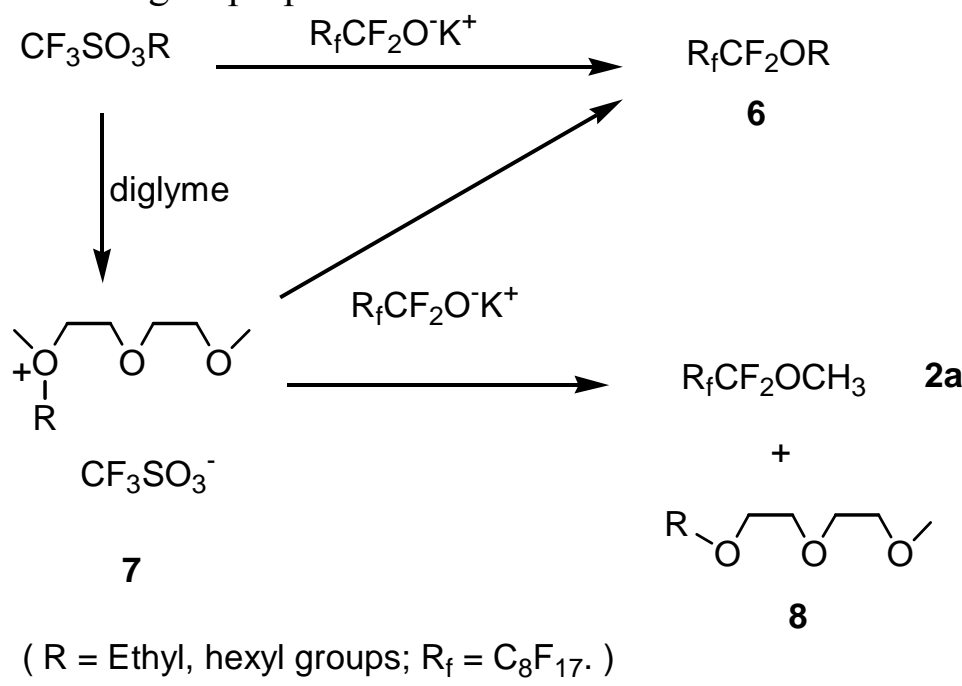

\section{Scheme 5}

At first, ethyl or hexyl triflate can react with diglyme solvent to form Meerwein-type ${ }^{31}$ oxonium ion 7, which can further methylate the fluorinated alkoxide to form $2 \mathbf{a}$. 


\section{Attempted reactions with other electrophiles}

We have also attempted to react fluorinated alkoxide 5a with other electrophiles, such as methyl iodide, acetyl chloride, benzoyl chloride, triflic anhydride, allyl bromide, acryloyl chloride, methyl chloroformate, propyl chloroformate, and $N, N$-carbonyl diimidazole (Scheme 6). Unfortunately, all these reactions did not give the expected products. This means that besides the facile formation of perfluoroalkoxides $\mathbf{5}$, very strong electrophilicity of the alkylating agents is also necessary (Scheme 6).

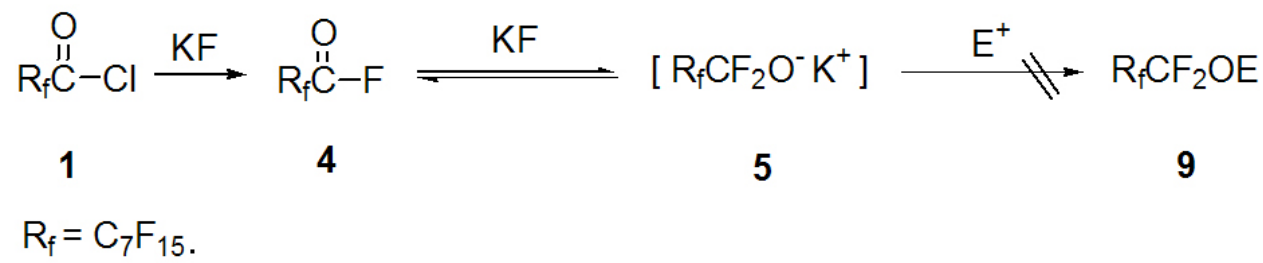

\section{Scheme 6}

\section{Attempted synthesis of partially fluorinated polyether}

With similar ether formation methodology methioned above, we also attempted to synthesize polyether $\mathbf{1 1}$ using ethylene glycol bistriflate $\mathbf{1 0}$ and hexafluoroglutaryl chloride $\mathbf{1 f}$ (Scheme 7).

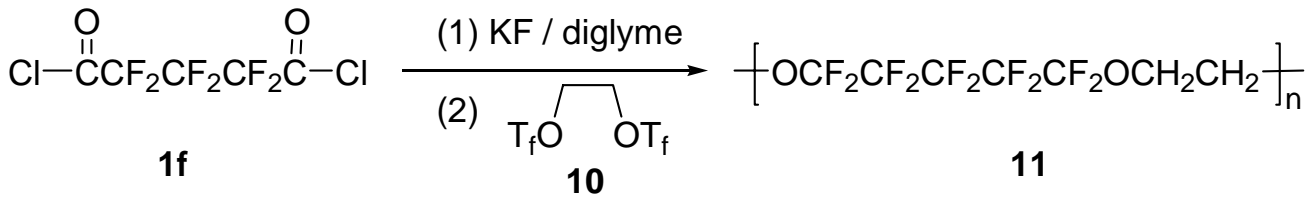

\section{Scheme 7}

Hexafluorofluoroglutaryl chloride $(3.6 \mathrm{mmol})$ was reacted with $\mathrm{KF}(21.6 \mathrm{mmol})$ in diglyme at $50{ }^{\circ} \mathrm{C}$ for $30 \mathrm{~min}$, followed by addition of ethylene glycol bistriflate $10(3.6 \mathrm{mmol})$ and the resulting reaction mixture was stirred at $70{ }^{\circ} \mathrm{C}$ for $20 \mathrm{~h}$. It turns out that the major products are some oligomeric compounds, and only around $5 \%$ yield of relatively high molecular weight polymer was obtained as an oily liquid (average molecular weight $=1,413$ according to SEC measurement using poly(ethylene oxide), PEO as a standard).

\section{Conclusions}

In conclusion, we have synthesized partially fluorinated ethers by the direct alkylation of fluorinated alkoxides generated in situ from fluoroacyl chlorides with potassium fluoride in diglyme. The success and yields of the reaction are affected by two factors: the stability and nucleophilicity of the fluorinated alkoxide generated in situ; and the other is the electrophilicity 
of alkylating agents. The new fluoroethers prepared have been found to be promising candidates for the lithium battery applications. ${ }^{38}$

\section{Experimental Section}

General Procedures. KF was dried at $300{ }^{\circ} \mathrm{C}$ under high vacuum for 10 hours and stored under argon. Diglyme was distilled over calcium hydride. Dimethyl sulfate was purchased from Aldrich chemical Co., and other fluoroacyl chlorides were purchased from Synquest laboratories, Inc. or prepared from the corresponding carboxylic acid with $\mathrm{PCl}_{5}$ or $\mathrm{SOCl}_{2}$.

${ }^{1} \mathrm{H},{ }^{13} \mathrm{C}$ and ${ }^{19} \mathrm{~F}$ NMR spectra were recorded on Bruker AMX 500 and AM 360 NMR spectrometers. ${ }^{1} \mathrm{H}$ NMR chemical shifts were determined relative to internal $\left(\mathrm{CH}_{3}\right)_{4} \mathrm{Si}$ (TMS) at $\delta$ 0.0 or to the signal of a residual protonated solvent: $\mathrm{CDCl}_{3} \delta 7.26 .{ }^{13} \mathrm{C} \mathrm{NMR}$ chemical shifts were determined relative to internal TMS at $\delta 0.0$ or to the ${ }^{13} \mathrm{C}$ signal of solvent: $\mathrm{CDCl}_{3} \delta$ 77.0. ${ }^{19} \mathrm{~F}$ NMR chemical shifts were determined relative to internal $\mathrm{CFCl}_{3}$ at $\delta 0.0$. Infrared spectra were obtained on a Perkin-Elmer Spectrum 2000 FT-IR spectrophotometer. Mass spectra were recorded on Hewlett Packard 5890 Gas Chromatograph with a Hewlett Packard 5971 Mass Selective Detector at $70 \mathrm{eV}$.

Methyl perfluorooctyl ether (2a). In a $200 \mathrm{ml}$ three-neck flask equipped with a dropping funnel, a magnetic stirring bar and condenser, was added $5.23 \mathrm{~g}$ of anhydrous KF (90 mmol) and $16 \mathrm{ml}$ of freshly distilled diglyme under argon atmosphere. The temperature was raised to $50{ }^{\circ} \mathrm{C}$, and $13.0 \mathrm{~g}$ perfluorooctanoyl chloride was added in slowly via dropping funnel over 30 minutes period. Then the temperature was raised to $70{ }^{\circ} \mathrm{C}$ and $7.57 \mathrm{~g}$ dimethyl sulfate $(60 \mathrm{mmol})$ was dropped in slowly, and the reaction mixture was kept stirring at $70 \sim 100{ }^{\circ} \mathrm{C}$ for another 1 hour. The mixture was cooled and stirred overnight at room temperature. The volatile material ( $25 \mathrm{~g})$ was distilled into a liquid nitrogen trap under high vacuum, followed by washing with cold $10 \%$ $\mathrm{NaOH}$ aqueous solution, brine and water respectively. After drying over anhydrous sodium sulfate, the crude product mixture was fractionally distilled. Totally $10.8 \mathrm{~g}$ (80\% yield) of $2 \mathbf{a}$ was isolated as colorless liquid, b.p. $61{ }^{0} \mathrm{C} / 26 \mathrm{mmHg} .{ }^{1} \mathrm{H} \mathrm{NMR}\left(\mathrm{CDCl}_{3}\right): \delta 3.73(\mathrm{~s}, 3 \mathrm{H}) ;{ }^{13} \mathrm{C}$ $\mathrm{NMR}\left(\mathrm{CDCl}_{3}\right): \delta 51.25(\mathrm{t}, \mathrm{J}=7.7 \mathrm{~Hz}), 109.38 \sim 120.15(\mathrm{~m}) ;{ }^{19} \mathrm{~F} \mathrm{NMR}\left(\mathrm{CDCl}_{3}\right): \delta-81.49(\mathrm{t}, \mathrm{J}=9.2$ $\mathrm{Hz}, 3 \mathrm{~F}),-88.76(\mathrm{~m}, 2 \mathrm{~F}),-122.57(\mathrm{~m}, 4 \mathrm{~F}),-122.87(\mathrm{~m}, 2 \mathrm{~F}),-123.33(\mathrm{~m}, 2 \mathrm{~F}),-125.85(\mathrm{~m}, 2 \mathrm{~F})$, 126.77 (m, 2F). IR (neat): 2976, 1793, 1460, 1349, 1206, 1010, 879, 723, 704, 659, 561, $529 \mathrm{~cm}^{-}$ 1. MS (relative intensity): $449\left(0.7, \mathrm{M}^{+}-1\right), 431\left(30, \mathrm{M}^{+}-\mathrm{F}\right), 381$ (18), 331 (6), 281 (2), 231 (6), 181 (9), 169 (20), 131 (35), 119 (21), 100 (15), 81 (100), 59 (50).

Methyl perfluorononanoyl ether (2b). In a $50 \mathrm{ml}$ three-neck flask equipped with a condenser, a stirring bar and two rubber septa, was added $2.41 \mathrm{~g}$ anhydrous KF (41 mmol) and $10 \mathrm{ml}$ of dry diglyme under argon atmosphere. At $50{ }^{\circ} \mathrm{C}, 5.0 \mathrm{~g}$ perfluorononanoyl chloride $(10 \mathrm{mmol})$ was added in slowly via a syringe. After 30 minutes at $50{ }^{\circ} \mathrm{C}$, the temperature was raised to $70{ }^{0} \mathrm{C}$ slowly, followed by slow addition of $3.92 \mathrm{~g}$ dimethyl sulfate $(30 \mathrm{mmol})$. The reaction mixture 
was stirred at $70{ }^{\circ} \mathrm{C}$ for 1 hour, then at $100{ }^{\circ} \mathrm{C}$ for another 1 hour. The reaction mixture was cooled, and stirred overnight at room temperature. The reaction mixture was mixed with $20 \mathrm{ml}$ of ether and washed with cold $10 \% \mathrm{NaOH}$ aqueous solution for 3 times. The ether layer was washed with brine and water 3 times, respectively. The ether phase was dried over magnesium sulfate. After filtration, the solvent was evaporated. The crude product was fractionally distilled and $3.66 \mathrm{~g}(71 \%)$ of $\mathbf{2 b}$ was isolated, b.p. $80-81{ }^{\circ} \mathrm{C} / 36 \mathrm{mmHg} .{ }^{1} \mathrm{H} \mathrm{NMR}\left(\mathrm{CDCl}_{3}\right): \delta 3.73(\mathrm{~s}, 3 \mathrm{H})$; ${ }^{13} \mathrm{C} \operatorname{NMR}\left(\mathrm{CDCl}_{3}\right): \delta 51.40(\mathrm{t}, \mathrm{J}=7.0 \mathrm{~Hz}) ; 105.28-122.00(\mathrm{~m}) ;{ }^{19} \mathrm{~F} \mathrm{NMR}\left(\mathrm{CDCl}_{3}\right): \delta-81.54(\mathrm{t}, \mathrm{J}$ $=9.3 \mathrm{~Hz}, 3 \mathrm{~F}),-88.81(\mathrm{~m}, 2 \mathrm{~F}),-122.56(\mathrm{~m}, 6 \mathrm{~F}),-122.88(\mathrm{~m}, 2 \mathrm{~F}),-123.34(\mathrm{~m}, 2 \mathrm{~F}),-125.88(\mathrm{~m}$, 2F), -126.81 (m, 2F). MS (relative intensity): 481 (0.1, $\left.\mathrm{M}^{+}-\mathrm{F}\right), 463$ (9), 413 (4), 281 (0.7), 231 (4), 181 (4), 169 (4), 151 (3), 131 (15), 119 (6), 100 (7), 81 (100), 69 (22), 51 (22).

Methyl perfluorodecanoyl ether (2c). In a $200 \mathrm{ml}$ three-neck flask equipped with a stirring bar, a condenser and two rubber septa, was added $5.0 \mathrm{~g}$ of anhydrous $\mathrm{KF}(86 \mathrm{mmol})$ and $20 \mathrm{ml}$ of dry diglyme under argon atmosphere. At $50{ }^{\circ} \mathrm{C}, 12.0$ g perfluorononanoyl chloride $(22 \mathrm{mmol})$ made from perfluorononanoic acid and thionyl chloride, was dissolved in $10 \mathrm{ml}$ diglyme and added in reaction mixture slowly via a syringe. After 30 minutes at $50{ }^{\circ} \mathrm{C}$, the temperature was raised up to $70{ }^{\circ} \mathrm{C}$ slowly, followed by the slow addition of $8.51 \mathrm{~g}$ dimethyl sulfate $(66 \mathrm{mmol})$. The reaction mixture was stirred at $70{ }^{\circ} \mathrm{C}$ for 1 hour, then at $100{ }^{\circ} \mathrm{C}$ for another hour. The reaction mixture was cooled, and stirred overnight at room temperature. The reaction mixture was added in $20 \mathrm{ml}$ of ether and washed with cold $10 \% \mathrm{NaOH}$ aqueous solution for 3 times. The ether layer was washed with brine and water 3 times, respectively. The ether phase was dried over magnesium sulfate. After filtration, the solvent was evaporated. The crude product was fractionally distilled and $7.68 \mathrm{~g}$ of $2 \mathrm{c}(62 \%)$ was isolated, b.p. $84-85{ }^{\circ} \mathrm{C} / 27 \mathrm{mmHg} .{ }^{1} \mathrm{H}$ NMR (acetone- $\left.\mathrm{d}_{6}\right): \delta 3.83(\mathrm{~s}, 3 \mathrm{H}) ;{ }^{13} \mathrm{C}$ NMR(acetone- $\left.\mathrm{d}_{6}\right): \delta 51.49(\mathrm{t}, \mathrm{J}=6.4 \mathrm{~Hz}) ; 106.14-123.16(\mathrm{~m})$; ${ }^{19} \mathrm{~F}$ NMR(acetone- $\left.\mathrm{d}_{6}\right): \delta-81.29(\mathrm{t}, \mathrm{J}=9.2 \mathrm{~Hz}, 3 \mathrm{~F}),-87.84(\mathrm{~m}, 2 \mathrm{~F}),-121.74(\mathrm{~m}, 8 \mathrm{~F}),-122.19(\mathrm{~m}$, 2F), -122.70 (m, 2F), -125.32 (m, 2F), -126.28 (m, 2F).

Chlorodifluoroacetyl chloride (1d). Chlorodifluoroacetic acid (100 g, 0.766 mol) reacts with 1.5 equiv. $\mathrm{PCl}_{5}(239 \mathrm{~g})$ at $90-100{ }^{\circ} \mathrm{C}$ for $3 \mathrm{~h}$, and the product was distilled out to give $40.5 \mathrm{~g}$ (36\% yield) 1d, ${ }^{34}$ b.p. $28-29{ }^{\circ} \mathrm{C},{ }^{19} \mathrm{~F} \mathrm{NMR}\left(\mathrm{CDCl}_{3}\right): \delta$-63.30. It was re-distilled before use.

2-Chloro-1,1,2,2-tetrafluoroethyl methyl ether (2d). In a $200 \mathrm{ml}$ three-neck flask equipped with a dry ice condenser, a stirring bar and two rubber septa, was added $20.0 \mathrm{~g}$ of anhydrous $\mathrm{KF}$ (430 mmol) and $20 \mathrm{ml}$ of dry diglyme under an argon atmosphere. At $50{ }^{\circ} \mathrm{C}, 6.0 \mathrm{~g}$ chlorodifluoroacetyl chloride $(40 \mathrm{mmol})$ made from chlorodifluoroacetic acid and phosphorus pentachloride, was added into the reaction mixture slowly via a syringe. After 30 minutes at $50{ }^{\circ} \mathrm{C}$, the temperature was raised to $70{ }^{\circ} \mathrm{C}$ slowly, followed by slow addition of $8.51 \mathrm{~g}$ dimethyl sulfate $(66 \mathrm{mmol})$. Reaction mixture was kept at $70{ }^{\circ} \mathrm{C}$ for 1 hour and then cooled down to room temperature, followed by stirring overnight. $10 \mathrm{ml}$ of $10 \% \mathrm{NaOH}$ aqueous solution was added into the reaction mixture, and the volatile product was fractionally distilled. Totally $3.24 \mathrm{~g} \mathrm{(48 \% )}$ 3d was isolated. ${ }^{1} \mathrm{H} \mathrm{NMR}\left(\mathrm{CDCl}_{3}, \mathrm{ppm}\right): \delta 3.73$ (s, 3H); ${ }^{13} \mathrm{C} \mathrm{NMR}\left(\mathrm{CDCl}_{3}\right): \delta 51.77$ (t, J = 6.1 $\mathrm{Hz}), 117.18\left(\mathrm{tt},{ }^{1} \mathrm{~J}_{\mathrm{C}-\mathrm{F}}=271.5 \mathrm{~Hz},{ }^{2} \mathrm{~J}_{\mathrm{C}-\mathrm{F}}=34.2 \mathrm{~Hz}\right), 120.77\left(\mathrm{tt},{ }^{1} \mathrm{~J}_{\mathrm{C}-\mathrm{F}}=299.1 \mathrm{~Hz},{ }^{2} \mathrm{~J}_{\mathrm{C}-\mathrm{F}}=45.2 \mathrm{~Hz}\right)$; ${ }^{19} \mathrm{~F} \mathrm{NMR}\left(\mathrm{CDCl}_{3}\right): \delta-73.11(\mathrm{t}, \mathrm{J}=3.0 \mathrm{~Hz}, 2 \mathrm{~F}),-93.09(\mathrm{t}, \mathrm{J}=3.0 \mathrm{~Hz}, 2 \mathrm{~F})$. 
2-Phenyl-2,2-difluoroacetyl chloride (1e) ${ }^{35,36}$. At $0{ }^{\circ} \mathrm{C}$, into $21.95 \mathrm{~g}$ (0.13 mol) methyl benzoylformate, was slowly added $25.85 \mathrm{~g}(0.16 \mathrm{~mol})$ (diethylamino)sulfur trifluoride (DAST). The reaction mixture was stirred at $0{ }^{\circ} \mathrm{C}$ for $0.5 \mathrm{~h}$ and then at $40{ }^{\circ} \mathrm{C}$ for another $4 \mathrm{~h}$. The reaction mixture was cooled to room temperature and poured into $50 \mathrm{ml}$ of ice water, followed by extraction with $50 \mathrm{ml} \mathrm{CH} \mathrm{Cl}_{2}$. The organic phase was washed with saturated $\mathrm{NaHCO}_{3}$ aqueous solution and water. After drying over $\mathrm{MgSO}_{4}$ and solvent removal, 22.9 g crude methyl 1,1difluorobenzylformate as a wine-red liquid, yield $92 \%$. ${ }^{1} \mathrm{H}$ NMR shows the purity to be above $96 \% .{ }^{1} \mathrm{H} \mathrm{NMR}\left(\mathrm{CDCl}_{3}\right): \delta 3.84(\mathrm{~s}, 3 \mathrm{H}), 7.40(\mathrm{~m}, 3 \mathrm{H}), 7.61(\mathrm{~d}, 2 \mathrm{H}) ;{ }^{13} \mathrm{C} \mathrm{NMR}\left(\mathrm{CDCl}_{3}\right): \delta 53.60$, $113.41(\mathrm{t}), 125.42,128.60,131.03,132.65(\mathrm{t}), 164.7 ;{ }^{19} \mathrm{~F} \mathrm{NMR}\left(\mathrm{CDCl}_{3}\right): \delta$ - 104.25.

Into $22.84 \mathrm{~g}(0.122 \mathrm{~mol})$ methyl 1,1-difluorobenzylformate was added $100 \mathrm{ml}$ of $2.5 \mathrm{M}$ aqueous $\mathrm{NaOH}$ solution and $60 \mathrm{ml}$ of THF, then the mixture was refluxed for $4 \mathrm{~h}$. The reaction mixture was cooled and extracted with $200 \mathrm{ml}$ of ether. The aqueous phase was acidified with $5 \% \mathrm{HCl}$ until $\mathrm{pH}$ paper test showed acidic. The aqueous phase was extracted with $100 \mathrm{ml}$ ether twice, and the combined ether phase was dried over $\mathrm{MgSO}_{4}$. After solvent removal, $18.05 \mathrm{~g}$ yellow liquid was obtained, into which $150 \mathrm{ml}$ hexane was added. The hexane solution was stored in refrigerator at $-10{ }^{\circ} \mathrm{C}$ overnight. and $9.06 \mathrm{~g}$ Needle-like crystalline product 2-phenyl-2,2difluoroacetic acid, was isolated by suction filtraction, $9.06 \mathrm{~g}$, yield $46 \%{ }^{1} \mathrm{H} \mathrm{NMR}\left(\mathrm{CDCl}_{3}\right): \delta$ $7.55(\mathrm{~m}, 3 \mathrm{H}), 7.62(\mathrm{~d}, 2 \mathrm{H}), 10.08(\mathrm{~b}, 1 \mathrm{H}) ;{ }^{13} \mathrm{C} \mathrm{NMR}\left(\mathrm{CDCl}_{3}\right): \delta 112.99(\mathrm{t}, \mathrm{J}=252.3 \mathrm{~Hz}), 125.52$, 128.79, 131.43, $131.85(\mathrm{t}, \mathrm{J}=25.1 \mathrm{~Hz}), 169.25(\mathrm{t}, \mathrm{J}=36.1 \mathrm{~Hz}) ;{ }^{19} \mathrm{~F} \mathrm{NMR}\left(\mathrm{CDCl}_{3}\right): \delta-105.85$.

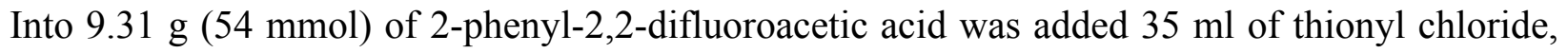
and the mixture was refluxed for $10 \mathrm{~h}$ under argon. Fractional distillation gave $9.4 \mathrm{~g}$ 2-phenyl2,2-difluoroacetyl chloride (1e), yield $91 \%$, b.p. $67{ }^{\circ} \mathrm{C} / 15 \mathrm{mmHg} .{ }^{1} \mathrm{H} \mathrm{NMR}\left(\mathrm{CDCl}_{3}\right): \delta 7.51(\mathrm{t}$, $3 \mathrm{H}), 7.58(\mathrm{t}, 1 \mathrm{H}), 7.63(\mathrm{~d}, 2 \mathrm{H}) ;{ }^{13} \mathrm{C} \mathrm{NMR}\left(\mathrm{CDCl}_{3}\right): \delta 114.41(\mathrm{t}, \mathrm{J}=259.0 \mathrm{~Hz}), 125.95(\mathrm{t}, \mathrm{J}=6.0$ $\mathrm{Hz}), 129.03,130.02$, (t, $\mathrm{J}=26.1 \mathrm{~Hz}), 131.95,167.31(\mathrm{t}, \mathrm{J}=50 \mathrm{~Hz}) ;{ }^{19} \mathrm{~F} \mathrm{NMR}\left(\mathrm{CDCl}_{3}\right): \delta-$ 101.32.

Methyl 2-phenyl-1,1,2,2-tetrafluoroethyl ether (2e). In a $200 \mathrm{ml}$ three-neck flask equipped with a stirring bar, a condenser and two rubber septa, was added $8.6 \mathrm{~g}$ of anhydrous KF (148 $\mathrm{mmol})$ and $20 \mathrm{ml}$ of dry diglyme under an argon atmosphere. At $50{ }^{\circ} \mathrm{C}, 8.5 \mathrm{~g} 1 \mathrm{e}(44 \mathrm{mmol})$ was added into the reaction mixture slowly via syringe. After 30 minutes at $50{ }^{0} \mathrm{C}$, the temperature was raised up to $70{ }^{\circ} \mathrm{C}$ slowly, followed by slow addition of $11.25 \mathrm{~g}$ dimethyl sulfate $(89 \mathrm{mmol})$. The reaction mixture was stirred at $70{ }^{\circ} \mathrm{C}$ for 1 hour, then at $100{ }^{\circ} \mathrm{C}$ for another 2 hours. The reaction mixture was cooled, and stirred overnight at room temperature. The reaction mixture was mixed with $20 \mathrm{ml}$ of $\mathrm{CH}_{2} \mathrm{Cl}_{2}$ and washed with cold $10 \% \mathrm{NaOH}$ aqueous solution trice. The organic layer was washed with brine and water trice, respectively. The organic phase was dried over magnesium sulfate and the solvent was evaporated off. After column chromatography using hexanes as eluent, $2.10 \mathrm{~g}(23 \%)$ of $2 \mathbf{e}$ was isolated as a corlorless liquid. ${ }^{1} \mathrm{H}\left(\mathrm{CDCl}_{3}\right): \delta 3.61$ (s, $3 \mathrm{H}), 7.45(\mathrm{t}, 2 \mathrm{H}), 7.51(\mathrm{t}, 1 \mathrm{H}), 7.59(\mathrm{~d}, 2 \mathrm{H}) ;{ }^{13} \mathrm{C}\left(\mathrm{CDCl}_{3}\right): \delta 51.03(\mathrm{t}, \mathrm{J}=6.7 \mathrm{~Hz}), 119.24\left(\mathrm{tt},{ }^{1} \mathrm{~J}_{\mathrm{C}-\mathrm{F}}\right.$ $\left.=271 \mathrm{~Hz},{ }^{2} \mathrm{~J}_{\mathrm{C}-\mathrm{F}}=36 \mathrm{~Hz}\right), 114.44\left(\mathrm{tt},{ }^{1} \mathrm{~J}_{\mathrm{C}-\mathrm{F}}=271 \mathrm{~Hz},{ }^{2} \mathrm{~J}_{\mathrm{C}-\mathrm{F}}=36 \mathrm{~Hz}\right), 130.86(\mathrm{t}, \mathrm{J}=24.5 \mathrm{~Hz}), 126.61$ $(\mathrm{t}, \mathrm{J}=6.7 \mathrm{~Hz}), 128.18,130.98 ;{ }^{19} \mathrm{~F}\left(\mathrm{CDCl}_{3}\right): \delta-93.81(\mathrm{t}, \mathrm{J}=4.9 \mathrm{~Hz}, 2 \mathrm{~F}),-114.08(\mathrm{t}, \mathrm{J}=4.9 \mathrm{~Hz})$. 
MS (relative intensity): $208\left(27, \mathrm{M}^{+}\right), 189\left(4, \mathrm{M}^{+}-\mathrm{F}\right), 177\left(0.3, \mathrm{PhCF}_{2} \mathrm{CF}_{2}^{+}\right), 127\left(100, \mathrm{PhCF}_{2}^{+}\right)$, $81\left(21, \mathrm{CH}_{3} \mathrm{OCF}_{2}^{+}\right), 77\left(9, \mathrm{Ph}^{+}\right), 51(4)$.

1,5-Dimethoxy-perfluoropentane (2f). In a $50 \mathrm{ml}$ three-neck flask equipped with a dropping funnel, a magnetic stirring bar and a condenser, was added $6.22 \mathrm{~g}$ of anhydrous KF (107 mmol) and $10 \mathrm{ml}$ of freshly distilled diglyme under an argon atmosphere. The temperature was raised to $50{ }^{\circ} \mathrm{C}$, and $1.64 \mathrm{~g}(5.92 \mathrm{mmol}) \mathbf{1 f}$ was added in slowly via syringe. Then the temperature was raised to $70{ }^{\circ} \mathrm{C}$ and $3.78 \mathrm{~g}$ dimethyl sulfate $(30 \mathrm{mmol})$ was dropped in slowly, and the reaction was kept stirred at $70 \sim 100{ }^{\circ} \mathrm{C}$ for another 1 hour. The reaction mixture was cooled and stirred overnight at room temperature. The reaction mixture was washed with $10 \% \mathrm{NaOH}$ aqueous solution and extracted with $\mathrm{CH}_{2} \mathrm{Cl}_{2}$, and the organic phase was washed with brine and water, respectively. After drying over magnesium sulfate, the solvent was evaporated. After fractional distillation, about $5 \mathrm{~g}$ crude product was isolated, which contains diglyme. The diglyme was removed by washing with water and extracted with diethyl ether 10 times. After drying and removal of the solvent, $0.92 \mathrm{~g}(50 \%$ yield $)$ of $\mathbf{2 f}$ was isolated as a colorless liquid. ${ }^{1} \mathrm{H}\left(\mathrm{CDCl}_{3}\right): \delta$ $3.72(\mathrm{~s}, 3 \mathrm{H}) ;{ }^{13} \mathrm{C}\left(\mathrm{CDCl}_{3}\right): \delta 51.44(\mathrm{t}, \mathrm{J}=6.8 \mathrm{~Hz}), 105.58 \sim 120.22(\mathrm{~m}) ;{ }^{19} \mathrm{~F}\left(\mathrm{CDCl}_{3}\right): \delta-88.80(\mathrm{t}, \mathrm{J}$ $=9.2 \mathrm{~Hz}, 4 \mathrm{~F}),-123.36(\mathrm{~m}, 2 \mathrm{~F}),-126.01(\mathrm{~m}, 4 \mathrm{~F})$. MS (relative intensity): $311\left(0.07, \mathrm{M}^{+}\right), 293$ (18), 243 (2), 231 (5), 197 (0.7), 181 (3), 169 (10), 131 (9), 119 (3), 112 (4), 100 (7), 81 (100, $\mathrm{CH}_{3} \mathrm{OCF}_{2}^{+}$), 69 (10).

Methyl triflate as the alkylating agent. In a $50 \mathrm{ml}$ three-neck flask equipped with a magnetic stirring bar and a condenser, was added $0.54 \mathrm{~g}(9.3 \mathrm{mmol})$ of anhydrous $\mathrm{KF}$ and $10 \mathrm{ml}$ of freshly distilled diglyme under argon atmosphere. The temperature was raised to $50{ }^{\circ} \mathrm{C}$, and $1.0 \mathrm{~g}(2.3$ mmol) perfluorooctanoyl chloride was slowly added in via a syringe. Then the temperature was raised to $70{ }^{\circ} \mathrm{C}$ and $0.76 \mathrm{~g}$ methyl triflate $(4.6 \mathrm{mmol})$ was added in via syringe, and the reaction was kept stirredat $70 \sim 100{ }^{\circ} \mathrm{C}$ for another 2 hours. The reaction mixture was cooled and stirred overnight at room temperature. The reaction mixture was stirred in cold $30 \% \mathrm{NaOH}$ aqueous solution $(10 \mathrm{ml})$ for $30 \mathrm{~min}$, followed by extraction with $15 \mathrm{ml}$ ether twice. The ether phase was washed with brine and water respectively. After drying over anhydrous sodium sulfate, the crude product mixture was fractionally distilled to afford $0.85 \mathrm{~g}(82 \%$ yield $)$ of the product as a colorless liquid. ${ }^{1} \mathrm{H},{ }^{13} \mathrm{C},{ }^{19} \mathrm{~F}$ NMR and $\mathrm{MS}$ spectra indicate the product to be Methyl perfluorooctyl ether $\mathbf{2 a}$.

The reaction conditions for the methyl mesylate and methyl tosylate as alkylating agents are similar, except that the reaction times are longer $(\sim 20 \mathrm{~h})$. The isolated yields of $2 \mathrm{a}$ are $29 \%$ and $17 \%$ respectively.

Ethyl triflate as alkylating agent. In a $100 \mathrm{ml}$ three-neck flask equipped with a magnetic stirring bar and a condenser, was added $2.69 \mathrm{~g}(46.2 \mathrm{mmol})$ of anhydrous $\mathrm{KF}$ and $10 \mathrm{ml}$ of freshly distilled diglyme under an argon atmosphere. The temperature was raised to $50{ }^{\circ} \mathrm{C}$, and $5.0 \mathrm{~g}$ (11.6 mmol) perfluorooctanoyl chloride was slowly added in via a syringe. Then the temperature was raised to $70{ }^{\circ} \mathrm{C}$ and $2.06 \mathrm{~g}$ ethyl triflate $(11.6 \mathrm{mmol})$ was added in via syringe, and the reaction was kept stirred at $70 \sim 100{ }^{\circ} \mathrm{C}$ for another 2 hours. Then another $5 \mathrm{~g}$ of ethyl triflate $(28 \mathrm{mmol})$ was added into the reaction mixture and stirred at $100{ }^{\circ} \mathrm{C}$ for another $2 \mathrm{~h}$. The 
reaction mixture was cooled and stirred at room temperature. The reaction mixture was treated with cold $30 \% \mathrm{NaOH}$ aqueous solution $(15 \mathrm{ml}$ ) for $30 \mathrm{~min}$, followed by extraction with $15 \mathrm{ml}$ ether thrice. The ether phase was washed with brine and water respectively. After drying over anhydrous sodium sulfate, the crude product mixture was fractionally distilled to afford $4.54 \mathrm{~g}$ (85\% yield) of the product as a colorless liquid, b.p. $50-52{ }^{\circ} \mathrm{C} / 17 \mathrm{mmHg} .{ }^{1} \mathrm{H},{ }^{19} \mathrm{~F}$ NMR and GCMS showed that it contains two compounds: ethyl perfluorooctyl ether $\mathbf{6 d}$ and methyl perfluorooctyl ether 2a. The ratio of $\mathbf{6 d}: \mathbf{2 a}=2: 3$. For $\mathbf{6 d}$, ca. $34 \%$ yield. ${ }^{1} \mathrm{H}$ NMR $\left(\mathrm{CDCl}_{3}\right): \delta$ $1.36(\mathrm{t}, 3 \mathrm{H}), 4.13(\mathrm{q}, 2 \mathrm{H}) ;{ }^{13} \mathrm{C} \mathrm{NMR}\left(\mathrm{CDCl}_{3}\right): \delta 14.54,61.79(\mathrm{t}, \mathrm{J}=5.9 \mathrm{~Hz}), 104 \sim 120(\mathrm{~m}) ;{ }^{19} \mathrm{~F}$ NMR $\left(\mathrm{CDCl}_{3}\right): \delta-81.47(\mathrm{t}, \mathrm{J}=9.2 \mathrm{~Hz}, 3 \mathrm{~F}),-85.80(\mathrm{~m}, 2 \mathrm{~F}),-122.61(\mathrm{~m}, 4 \mathrm{~F}),-122.89(\mathrm{~m}, 2 \mathrm{~F})$, $123.40(\mathrm{~m}, 2 \mathrm{~F}),-125.86(\mathrm{~m}, 2 \mathrm{~F}),-126.77(\mathrm{~m}, 2 \mathrm{~F})$. MS (relative intensity): $463\left(7, \mathrm{M}^{+}-1\right), 449$ (13), 331 (4), 232 (7), 219 (13), 181 (15), 169 (36), 131 (55), 119 (34), 100 (33), 95 (40), 69 (100). For 2a, ca. $51 \%$ yield. The characterization data are same as above.

Hexyl triflate as the alkylating agent. In a $200 \mathrm{ml}$ three-neck flask equipped with a magnetic stirring bar and a condenser, was added $2.0 \mathrm{~g}$ (34 mmol) of anhydrous KF and $30 \mathrm{ml}$ of freshly distilled diglyme under an argon atmosphere. The temperature was raised to $50{ }^{\circ} \mathrm{C}$, and $5.0 \mathrm{~g}$ (11.6 mmol) perfluorooctanoyl chloride was slowly added in via a syringe. Then the temperature was raised to $70{ }^{\circ} \mathrm{C}$ and $4.06 \mathrm{~g}(17.4 \mathrm{mmol})$ of hexyl triflate was added in via syringe, and the reaction was kept stirred at $70 \sim 100{ }^{\circ} \mathrm{C}$ for another 2 hours. Then another $1.4 \mathrm{~g}(6 \mathrm{mmol})$ of hexyl triflate was added into the reaction mixture, and stirred at $90{ }^{\circ} \mathrm{C}$ overnight. The reaction mixture was cooled and stirred with cold $30 \% \mathrm{NaOH}$ aqueous solution $(20 \mathrm{ml})$ for $30 \mathrm{~min}$, followed by extraction with $15 \mathrm{ml}$ ether thrice. The ether phase was washed with brine and water respectively. After drying over anhydrous sodium sulfate and removal of the solvent, the crude product was further purified by silica gel column chromatography (hexanes as eluent) to afford $3.6 \mathrm{~g}$ (60\% yield) of hexyl perfluorooctyl ether $\mathbf{6 e}$ as a colorless liquid, and $0.78 \mathrm{~g}$ (15\% yield) 2a. For 6e, ${ }^{1} \mathrm{H}$ NMR $\left(\mathrm{CDCl}_{3}\right): \delta 0.90(\mathrm{t}, \mathrm{J}=6.6 \mathrm{~Hz}, 3 \mathrm{H}), 1.26-1.42(\mathrm{~m}, 6 \mathrm{H}), 1.69(\mathrm{~m}, 2 \mathrm{H}), 4.04(\mathrm{t}$, $\mathrm{J}=6.6 \mathrm{~Hz}, 2 \mathrm{H}) ;{ }^{13} \mathrm{C} \mathrm{NMR}\left(\mathrm{CDCl}_{3}\right): \delta 13.78,22.43,25.06,28.73,31.17,65.72(\mathrm{t}, \mathrm{J}=5.1 \mathrm{~Hz})$, 108.63-118.36 (m); ${ }^{19} \mathrm{~F}$ NMR $\left(\mathrm{CDCl}_{3}\right): \delta-81.26(\mathrm{t}, \mathrm{J}=9.5 \mathrm{~Hz}, 3 \mathrm{~F}),-85.68(2 \mathrm{~F}),-122.46(\mathrm{~b}, 4 \mathrm{~F})$, $-122.74(\mathrm{~b}, 2 \mathrm{~F}),-123.24(\mathrm{~b}, 2 \mathrm{~F}),-125.74(\mathrm{~b}, 2 \mathrm{~F}),-126.62$ (b, 2F). MS (relative intensity): 475 (0.7), 449 (0.7), 231 (1), 219 (2), 181 (3), 169 (10), 131 (30), 119 (16), 100 (12), 85 (15), 69 (100), 55 (73). For 2a, the characterization data are same as above.

Attempted reactions with other electrophiles. The reaction conditions for other electrophiles, such as methyl iodide, acetyl chloride, benzoyl chloride, triflic anhydride, allyl bromide, acryloyl chloride, methyl chloroformate, propyl chloroformate, and $N, N$-carbonyl diimidazole, are silimiliar as above. For some volatile substrates, dry ice condenser was used.

Attempted synthesis of partially fluorinated polyether (11): Ethylene glycol bistriflate $\mathbf{( 1 0}^{37}$. A mixture of dry ethylene glycol $(1 \mathrm{~g}, 16.1 \mathrm{mmol})$ and anhydrous pyridine $(3 \mathrm{ml})$ in dry methylene chloride $(30 \mathrm{ml})$, was added dropwise into an ice-cooled, stirred solution of triflic anhydride (9.1 g, $32.2 \mathrm{mmol})$ in $20 \mathrm{ml}$ of methylene chloride under argon. The solution was stirred for an additional $2 \mathrm{~h}$, then washed with water $(100 \mathrm{ml})$ and dried over $\mathrm{MgSO}_{4}$. After removal of the solvent, $4.5 \mathrm{~g}$ product $\mathbf{1 0}$ was obtained as a pale yellow crystalline solid, yield 86 
\%. ${ }^{1} \mathrm{H}$ NMR $\left(\mathrm{CDCl}_{3}\right): \delta 4.77\left(\mathrm{~s}, \mathrm{C}_{2}-\underline{\mathrm{H}}_{2}\right) ;{ }^{13} \mathrm{C} \mathrm{NMR}\left(\mathrm{CDCl}_{3}\right): \delta 71.72,118.53$ (q, J = 319.5 $\mathrm{Hz}) ;{ }^{19} \mathrm{~F} \mathrm{NMR}\left(\mathrm{CDCl}_{3}\right): \delta-74.77$.

Fluorinated polyether (11). In a $100 \mathrm{ml}$ three-neck round bottom flask, was added $1.26 \mathrm{~g}(21.7$ $\mathrm{mmol}$ ) of dry $\mathrm{KF}$ and $10 \mathrm{ml}$ of dry diglyme. At $50{ }^{\circ} \mathrm{C}, 1.0 \mathrm{~g}$ hexafluoroglutaryl chloride (3.6 mmol) was added via a syringe, and the reaction mixture was stirred for $30 \mathrm{~min}$. Then the temperature was raised to $70{ }^{\circ} \mathrm{C}$ and $1.18 \mathrm{~g}$ ethylene glycol bistriflate $(3.6 \mathrm{mmol})$ was added into the reaction mixture. The reaction mixture was stirred at $70{ }^{\circ} \mathrm{C}$ for another $1 \mathrm{~h}$ and then at $100{ }^{\circ} \mathrm{C}$ overnight. The reaction mixture was cooled and stirred with $30 \% \mathrm{NaOH}$ aqueous solution (10 $\mathrm{ml}$ ), and then extracted with $15 \mathrm{ml}$ ether thrice. Combined ether phase was washed with water twice. After drying over $\mathrm{MgSO}_{4}$ and solvent removal, the crude product was treated with high vacuum for $10 \mathrm{~h}$ to give $0.12 \mathrm{~g}$ of oily liquid $(\sim 5 \%$ yield $) .{ }^{19} \mathrm{~F} \mathrm{NMR}\left(\mathrm{CDCl}_{3}\right): \delta-85.8\left(-\mathrm{OCF}_{2}-\right.$, 4F), -123.1 (m, 2F), -125.9 (m, 4F). Size Exclusion Chromatography measurement with PEO standard curve gave the average molecular weight $M_{w}=1,413 ; M_{n}=1,316 ; M_{w} / M_{n}=1.07$.

\section{Acknowledgments}

Loker Hydrocarbon Research Institute and NASA-JPL (through a DARPA TRP program involving SAFT, America Inc.) are acknowledged for their financial support.

\section{References}

1. Hiyama, T. ed. Organofluorine Compounds: Chemistry and Applications, Springer-Verlag, New York, 2000, p 2.

2. (a) Banus, J.; Emeleus, H. J.; Haszeldine, R. N. J. Chem. Soc. 1951, 60. (b) Haszeldine, R. N.; Emeleus, H. J. Research 1948, 1, 715. (c) Haszeldine, R. N.; Sharpe, A. G. Fluorine and Its Compounds, Methuen, London, 1951, p 92. (d) Pearlson, W. H. Fluorine Chemistry, Vol. 1, Pergamon Press, Elmsford, N.Y., 1950, p 483. (e) Lovelace, L. M.; Rausch, D. A.; Postelnek, W. Aliphatic Fluorine Compounds, Reinhold, New York, 1958, p 137.

3. Olah, G. A.; Pavlath, A. Acta Chim. Acad. Sci. Hung. 1953, 3, 203, 425.

4. Weinmayer, V. J. Org. Chem. 1963, 28, 492.

5. Kloter, G.; Seppelt, K. J. Am. Chem. Soc. 1979, 101, 347.

6. Olah, G. A.; Mateescu, G. D. J. Am. Chem. Soc. 1971, 93, 781.

7. Minkwitz, R.; Reinemann, S. Z. Anorg. Allg. Chem. 1999, 625, 121.

8. Christe, K. O., personal communication.

9. Andreades S.; England, D. C. J. Am. Chem. Soc. 1961, 83, 4670.

10. (a) Redwood, M. E.; Willis, C. J. Can. J. Chem. 1965, 43, 1893. (b) Redwood, M. E.; Willis, C. J. Can. J. Chem. 1965, 45, 389.

11. Pittman, A. G.; Sharp, D. L. J. Polym. Sci., Part B, 1965, 3, 379. 
12. Evans, F. W.; Litt, M. H.; Weidler-Kubanek, A-M; Avonda, F. P. J. Org. Chem. 1968, 33, 1837.

13. Pittman, A. G.; Sharp, D. L.; Lundin, R. E. J. Polym. Sci., Part A-1 1966, 4, 2637.

14. Evans, F. W.; Litt, M. H.; Weidler-Kubanek, A-M; Avonda, F. P. J. Org. Chem. 1968, 33, 1839.

15. Knunyants, I. L.; Shokina, V. V.; Tyuleneva, V. V; Razumeeva, T. N. Izv. Akad. Nauk SSSR, Ser. Khim. 1972, 5, 1133. (English translation)

16. (a) Farnham, W. B.; Smart, B. E.; Middleton, W. J.; Calabrese, J. C.; Dixon, D. A. J. Am. Chem. Soc. 1985, 107, 4565. (b) Farnham, W. B.; Middleton, W. J. Eur. Pat. Appl. 1985, EP 164124.

17. Zurer, P. S. Chem. \& Eng. News 1993, Nov. 15, p 12.

18. Lamanna, W. M.; Flynn, R. M.; Vitcak, D. R.; Qiu, Z.-M. PCT Int. Appl. 1999, WO 9947480.

19. Takata, N., Mochizuki, T., Fujimoto, E., Sekiya, A., Jpn. Kokai Tokkyo Koho, 1998, JP 10045651.

20. Dams, R. J.; Qiu, Z.-M.; Smolders, Robert, R. L.; Coppens, D. M.; Nagase, M. PCT Int. Appl., 1999, WO 9916809.

21. Sekya, A.; Ito, H.; Yamashita, S.; Mochizuki, J. Jpn. Kokai Tokkyo Koho 1994, JP 06293686.

22. Wasaki, T.; Takada, N.; Fujimoto, E.; Sekya, A. Jpn. Kokai Tokkyo Koho 1997, JP 09040594.

23. Goto, Y.; Yamashita, S.; Ito, H.; Suga, A.; Mochizuki, J.; Nagasaki, N.; Sekya, A., Jpn. Kokai Tokkyo Koho 1995, JP 07179386.

24. Ito, H.; Goto, Y.; Yamashita, S.; Suga, A.; Mochizuki, J.; Nagasaki, N.; Sekya, A., Jpn. Kokai Tokkyo Koho, 1996, JP 08034755.

25. Behr, F. E.; Cheburkov, Y. PCT Int. Appl. 1999, WO 9937598.

26. (a) Goto, Y.; Yamashita, S.; Ito, H.; Suga, A.; Mochizuki, J.; Nagasaki, N.; Sekya, A. Jpn. Kokai Tokkyo Koho 1995, JP 07179387. (b) Ito, H.; Goto, Y.; Yamashita, S.; Suga, A.; Mochizuki, J.; Nagasaki, N.; Sekya, A. Jpn. Kokai Tokkyo Koho 1996, JP 08034754.

27. Sakaguchi, T.; Fujimoto, H.; Oshita, R.; Watanabe, H.; Noma, T.; Nishio, A. Jpn. Kokai Tokkyo Koho 1999, JP 11329491.

28. Nakajima, T.; Dan, K.; Koh, M.; Ino, T.; Shimizu, T. J. Fluorine Chem. 2001, 111, 167-174.

29. (a) Paquette, L. A. ed. Encyclopedia of Reagents for Organic Synthesis, John Wiley \& Sons: New York, 1995, p 2132-2135. (b) Suter, C. M. The Organic Chemistry of Sulfur, Wiley: New York, 1944, p 48-74. (c) Kaiser, E. T. The Organic Chemistry of Sulfur, Plenum: New York, 1977, p 649.

30. See 16a and the references therein.

31. Hassner A.; Stumer C. Organic Syntheses Base on Named Reactions and Unnamed Reactions, Pergamon: New York, 1994, p 250 and references therein.

32. Stevens, M. P. Polymer Chemistry, Oxford: New York, 1999, p 12. 
33. Carothers, W. H. J. Am. Chem. Soc. 1928, 50, 2548.

34. Corley, R. S.; Cohen, S. G.; Simon, M. S.; Wolosinski, H. T. J. Am. Chem. Soc. 1956, 78, 2608.

35. Parisi, M. F.; Gattuso, G.; Notti, A.; Raymo, F. M. J. Org. Chem. 1995, 60, 5174.

36. Kitazume, T.; Tsukamoto T.; Yoshimura, K. Chem. Comm. 1994, 1355.

37. Salomon, M. F.; Salomon, R. G. J. Am. Chem. Soc. 1979, 101, 4290.

38. Smart, M. C.; Ratnakumar, B. V.; Ryan-Mowrey, V. S.; Surampudi, R.; Prakash, G. K. S.; $\mathrm{Hu}$, J.; Cheung, I. J. Power Sources 2003, in press. 